\title{
Article
}

\section{Measuring the Financial Liberalization Index for Pakistan}

\author{
Muhammad Idrees ${ }^{1}$, Umar Hayat ${ }^{2}$ (D), Magdalena Radulescu ${ }^{3,4}, *$, Md Shabbir Alam ${ }^{5, *}$ (D), Abdul Rehman ${ }^{6, *}$ (D) \\ and Mirela Panait ${ }^{7}$ (D)
}

check for

updates

Citation: Idrees, Muhammad, Umar Hayat, Magdalena Radulescu, Md Shabbir Alam, Abdul Rehman, and Mirela Panait. 2022. Measuring the Financial Liberalization Index for Pakistan. Journal of Risk and Financial Management 15: 57. https://doi.org/ 10.3390/jrfm15020057

Academic Editor: Ştefan

Cristian Gherghina

Received: 27 October 2021

Accepted: 15 January 2022

Published: 26 January 2022

Publisher's Note: MDPI stays neutral with regard to jurisdictional claims in published maps and institutional affiliations.

Copyright: (C) 2022 by the authors. Licensee MDPI, Basel, Switzerland. This article is an open access article distributed under the terms and conditions of the Creative Commons Attribution (CC BY) license (https:// creativecommons.org/licenses/by/ $4.0 /)$.
1 Department of Economics, University of Peshawar, Peshawar 25120, Khyber Pakhtunkhwa, Pakistan; muhammadidreestalal@gmail.com

2 Department of Economics and Development Studies, University of Swat, Mingora 19200, Khyber Pakhtunkhwa, Pakistan; umarhayat@uswat.edu.pk

3 Faculty of Economics and Law, University of Pitesti, Bd. Republicii, No. 71, 110062 Pitesti, Arges, Romania

4 Institute of Doctoral and Postdoctoral Studies, University "Lucian Blaga" of Sibiu, Bd. Victoriei, No. 10, 550024 Sibiu, Romania

5 Department of Economics and Finance, College of Business Administration, University of Bahrain, Sakhir 32038, Bahrain

6 College of Economics and Management, Henan Agricultural University Zhengzhou, Zhengzhou 450002, China

7 Department of Cybernetics, Economic Informatics, Finance and Accounting, Faculty of Economic Sciences, University Petroleum \& Gas Ploiesti, 100680 Ploiesti, Romania; mirela.matei@upg-ploiesti.ro

* Correspondence: magdalena.radulescu@upit.ro (M.R.); shabbir.alam28@gmail.com (M.S.A.); abdrehman@henau.edu.cn (A.R.)

\begin{abstract}
This paper aims to construct a bi-directional, financial liberalization index for Pakistan by considering various financial policy indicators (reforms). This study, by employing the principal component analysis method over a period of 1980-2018 (39 years), aims to determine the composite outcome in the case of developing a financial index. This study uses 14 financial policy indicators to investigate the degree of financial liberalization over a specified time period. The present study suggests a financial liberalization index for Pakistan considering the real-time change in the implementation process. The formulated index revealed that the recorded profitability of financial reforms was consistently high until 1998. Meanwhile, in the period from 1997 to 2003, the outcomes of financial reforms were surprisingly strong. Beyond 2004 and for the rest of the remaining years until 2018, the liberalization process recorded was comparatively slow. Thus, it was witnessed that all the key indicators, in the sense of regulation and liberalization, included determining the degree of financial liberalization. The consistency track of a liberalization index is a major focus of attention for policy makers, in order to capture the efficiency outcomes from various financial policy indicators, which were implemented beyond 2004. Furthermore, corporate risk in terms of better access to finance is also raised as a consequence of financial liberalization. Financial liberalization also resulted in a decrease in the cost of capital and improved the corporate governance.
\end{abstract}

Keywords: financial liberalization index (FLI); Pakistan; principal component analysis (PCA)

\section{Introduction}

In the last decade, financial liberalization systems played an important role in economic policy implication toward developing countries. Financial sector liberalization processes are realized to make financial institutions self-sufficient for easing financial repression. Financial liberalization reforms aim to provide opportunities for financial improvement. Moreover, they help to shrink directed credits and assist the external flow of financial capital in the home country (Demetriades and Andrianova 2004). The practice of financial liberalization began in different time periods in various parts of the world. It is an undeniable fact that technological advancement provides a crucial contribution to the growth rate in both developed and less-developed countries, but the absorption 
and consistency of each technology requires massive investments directed by banks. In early 1970, the infrastructure development emphasized by developing countries assumed that investment would be one of the largest opportunities for economic development and industrialization. Therefore, at that time, most developing countries were intensely focused on Information and Communication Technology (ICT), roads, buildings, bridges, research institutions, etc. They believed that a well-furnished infrastructure would encourage the private sector to invest in upcoming projects that would encourage the economic growth of the country (Akhtar and Alam 2011). Therefore, the expansion process in the main agriculture, service and industry sectors would lead to a targeted growth rate (Alam et al. 2021). Unfortunately, the inefficient use of resources indicated that the private sector could not be further invested in due to financial repression from regulatory authorities, mismanagement and governance problems. However, there are still gaps remaining in financing and investment decision interactions, the competitive environment, organizational structure, and sustainable investments, technologies and strategies. Risk management policies became a priority (Bui et al. 2020).

When an infrastructural process fails, in that circumstance, the developing countries shift from infrastructure development to financial sector liberalization and development. McKinnon (1973) encompassed the hypothesis on financial control for developing countries. They affirmed that financial liberalization through different policies would encourage saving, which would increase investment and economic growth in the country. Therefore, liberalizing interest rates through different reforms would increase both saving and productive investment. On the contrary, the neoclassical approach states that financial liberalization increases the inflation rate and damages the country's economic development (Singh 2003).

Therefore, to overcome the financial sector's control, the GoP started various financial reforms in the early 1980s under the governance of structural adjustment programs. During the early phase, prominent financial policies included the privatization of public banks, retrieval of banking credits and implementation of other policies toward efficient financial attainment and, subsequently, reforms associated with financial markets, such as the permission for subsidiaries, low capital ratios for banks and asset administration. Consumer financing was also familiarized in the same decade to maintain lower- and middle-level income division (Munir et al. 2013). The term, financial liberalization, encompasses the removal of financial repression, restrictions and government control toward financial indicators, encouraging financial prospects through financial reforms. Therefore, Pakistan started the implementation of financial liberalization in the late 1980s (Hye and Wizarat 2013). Some of the financial measures were used to broaden the financial system. Various policy tools were adopted to improve the efficiency of the financial sector. A well-structured financial set-up plays a significant role in encouraging the economic growth of a country. Some of the monetary and other financial policies were implemented, such as privatization, non-performing loans, institutional strengthening, debt management, monetary management, exchange and payment reforms, capital markets, banking reforms, prudential regulation, Islamization, interest rate deregulation, credit control, stock markets and the removal of barriers to entry. The main purpose of these policies is to reduce governmental intervention and controls and to liberalize financial structures. Some of these financial indicators aimed to increase effectiveness and competition in the financial sector. From all the above financial indicators, it was expected that objective functioning and the competition of money and the capital market would be attained.

The liberalization process of the financial sector was initiated under manifolds in the year 1980 in Pakistan. The financial policy indicators (reforms) from 1990 to 2018 are categorized by SBP as Privatization,

Non-performing loan, Institutional strengthening, Debt management, Monetary management, Exchange and payment reforms, Capital market, Banking reforms, Prudential regulation, Islamization, Interest rate deregulation, Credit control, Corporate risk and Removal of barrier to entry. 
According to the paradigm of financial liberalization, developing countries started the financial liberalization measure in the early 1980s (Hye and Wizarat 2013). It yielded remarkable results and motivated countries' financial systems. However, financial liberalization also causes fragility and the crisis of financial setup. During 1997, the Asian financial crisis appeared in financial liberalization setup (Arphasil 2001). Griffith-Jones et al. (2003) found that the rapid liberalization of capital accounts was the major cause of the 1990s crisis, particularly for developing countries. This study also has a background reality concerning developed and developing economies; therefore, a well-composed financial index based on various dimensions provides a prosperous approach to economic encouragement. Various studies were conducted in different parts of the world, for instance: Okoye et al. (2016) investigated the impact of the financial liberalization index on economic growth in Nigeria. The federal government of Nigeria consolidated financial deepening strengthened through financial liberalization, in order to reduce price levels and decrease the cost of production. One particular study also examined the indirect relationship between financial sector liberalization and the economic growth of the developing country. A study by Azmeh et al. (2017) used various proxies: foreign banks used for financial liberalization, claims on private sector shares to GDP, and liquidity liabilities used as proxies for financial development. The study found that foreign banking has a negative impact on financial development. Moreover, the study concluded that more banking openness decreased the economic growth of developing countries.

The basic framework of financial liberalization was initiated by the International Monetary Fund and World Bank, particularly for members of developing countries, in order to accelerate economic growth. The abstraction of financial liberalization, traced back to Bagehot (1873) argued that the financial system encompasses a better technology system that affects resource mobilization and improves economic health. However, the liberalization concept gained distinction in the influential work of McKinnon (1973) and Shaw (1973), who defined financial repression as a set of governmental restrictions on financial intermediaries from their full capacity level. Financial liberalization can be maintained by considering savings, interest rates and investment, all of which positively affect economic growth. The liberalization index covers the important dimension related to domestic financial sector reforms and scales the time and magnitude of various reforms taken during the process of financial sector liberalization. Empirically, the subject matter of the exact financial policy indicators, in terms of the control and efficiency status of the financial liberalization index, remains unsettled. This study tries to fill this gap by analyzing the effect of the updated position of various financial reforms in different financial sectors. Our goal is similar to the works of McKinnon (1973), Demetriades and Luintel (1997) and (Hye and Wizarat 2013). However, our goal modifies the level of analysis in the following ways. Firstly, the techniques, structure and scope of our empirical model are much more widespread than the works of Demetriades and Luintel (1997) and Hye and Wizarat (2013). Our model explicitly justifies the interactions and measurement level of the financial liberalization index. Secondly, our FLI degree of measure is more complex as it is an index of Pakistan's financial sector using a principal component analysis (PCA) of fourteen standard measures of financial liberalization level. Our index findings consider the variation effect that was used in the liberalization framework of McKinnon (1973) and Shaw (1973). The degree of our principle component analysis (PCA) measure for the index captures the maximum variance across various components in our sample period, which indicates an enhanced direction of the financial liberalization process and covers the multi-dimensions of the financial sector.

The objective purpose of this study is to develop a financial liberalization index (FLI) from different financial policy indicators by employing the principal component analysis (PCA) method. Section 2 comprises a review of the literature. Section 3 is based on developing a financial liberalization index (FLI). 


\subsection{Financial Sector Reforms}

In late 1980s, Pakistan commenced the structure of financial liberalization with the assistance of the World Bank (WB) and the IMF, in the context of the financial repression experienced in the 1970s. The key objective of the financial policies was to equally maintain financial institutions and the market by introducing competition, eliminating falsification in the financial market and encouraging financial productivity. This study included fourteen financial liberalization indicators: Privatization, Non-performing loan, Institutional strengthening, Debt management, Monetary management, Exchange and payment reforms, Capital market, Banking reforms, Prudential regulation, Islamization, Interest rate deregulation, Credit control, Stock market, and Removal of barrier to entry. These reforms shift the financial sector from a controlled to a fully liberalized environment with credit, exchange, and outstanding monetary roles. The reforms were also limited to removing segmentation and improving competition among financial institutions. Certainly, the financial sector development indicators showed an expansion after the introduction of reforms, including stock market capitalization, credit to GDP and M2/GDP (Khan and Qayyum 2007).

Currently, Pakistan's financial sector follows a monetary policy under market-based policies, the securities market, determination of the market through exchange and interest rates, and the convertibility of current to capital account liberalization. However, to benefit from domestic requirements and successfully integrate into the international market, the further openness, broadening, development, deepening and strengthening of the financial sector will need to achieve a successful growth rate. In order to overcome the financial crisis, financial institution de-regulation must be controlled and avoided. In response to this, financial sector policy makers should adopt and implement financial policy indicators, for instance non-performing loans, institutional strengthening and privatization, etc.

\subsection{Theoretical Background}

The topic of modern financial systems is diverse in the literature. However, despite this extensive research, mainstream research works were influenced by the foundational frameworks of various authors. These few studies concentrated on the liberalization, development and openness of various financial policy indicators. The study by Goldsmith (1969) covers financial development, which aims to comprehend financial structures and institutions, in order to capture economic growth by means of formulated financial indicators. Many studies introduce the notion of financial repression from the regulation of financial development. The literature of this repressed system is traced back to the study and hypothesis of McKinnon (1973) and Shaw (1973). The outline of these frameworks is based on control and intervention from the Government, which weakens and fragments the domestic capital market. The major contribution of McKinnon and Shaw was to identify the repressed gap in order to liberalize these financial indicators through policy variables.

Banks have a dominant support and function in all financial actions. In many aspects, banks are the backbone of the financial system in the economy because they provide funds to both consumers and businesses and act as intermediations between borrowers and savers.

The role of banks in developing countries is even more critical due to the absence of efficient financial setup. Companies and large business in developing economies depend on both domestic and international banks to make the required investments and capital for their growth (Morris et al. 1990; Rojas-Suárez and Weisbrod 1995). However, a publicly owned bank plays a dominant role in the prominence of the financial liberalization process, but this dominancy diminishes the strength of private sector banks and is the harbinger of crises. The prospects of overcoming financial crises by compensating with liberalization were discussed in various studies.

Essentially, financial sector liberalization means the removal of numerous financial restrictions with various aims, for instance: capital accounts, the flow of funds and financial transactions of businesses and individuals for the productive allocation of efficient resources. More generally, it is the process of policy implementation toward various financial policy 
indicators (financial reforms variables) through which the economy establishes a financial market via market forces with outstanding outcomes, as the index later interprets in detail.

Financial liberalization brings a progressive distinction to financial institutions and their structures. Williamson and Mahar (1998) argued that a market provides the right to determine the price at which credit is obtained and granted. Johnston and Sundararajan (1999) stated that financial liberalization can be viewed as a policy measure to deregulate and transform a regulated or repressed financial system into a liberalized regulatory framework.

However, the liberalization of the financial sector is often defined as the decline of control indicators that depict financial repression in order to liberalize the effect of financial characteristics. This explanation was provided by Beim and Calomiris (2001) in their work, which explained that financial liberalization specifies a mixture of the following financial indicators in terms of constraint relaxation. For instance: interest rate deregulation, declining the requirement of bank reserves, no governmental intervention, bank privatization, increasing competition between foreign banks and capital flow inspiration.

\section{Review of Literature}

McKinnon (1973) and Shaw (1973) investigated the term "financial repression". The hypothesis showed that the interest rate ceiling deteriorated saving, productive investment, and the growth of the country. Next, we review different studies which support the McKinnon and Shaw hypothesis.

Adeel-Farooq et al. (2017) used a principal component analysis to create a composite financial liberalization index that used the ARDL technique, which allows for a varying order of integration. The findings of the study revealed that financial liberalization has a positive association with the growth rate of Pakistan in the long term, while financial liberalization in India has a positive and significant impact to growth in both the short and long term. Khan and Qayyum (2007) examined the long-term growth in trade and financial liberalization in Pakistan. Celik and Citak (2016) empirically investigated the relations between financial liberalization, banking sector competition, real investment financing and economic growth, rooted in the McKinnon and Shaw framework. The findings of the existing study concluded that banking sector competition has a positive effect, and financial liberalization has a negative effect, on the economic growth rate in Turkey. Kiyota et al. (2007) found that the privatization of local companies and opening of foreign banks benefited from financial liberalization. Tang and Liu (2018) used the Mattoo financial liberalization index in Vietnam to measure the degree of financial sector liberalization. The study that constructed the Mattoo index was actually based on classifying the rules and regulations of banking and insurance directions, in order to investigate the level of financial liberalization in Vietnam. The outcome of the Mattoo index is likely higher than in Asia and the Pacific. The study concluded that banking has a higher liberalization, and insurance has a lower liberalization, compared to the average global rate. Mattoo et al. (2006), using a sample with respondents from over 59 countries, confirmed that financial service liberalization has a momentous effect on a country's growth rate. Pineda (2017) estimated the optimal debt/net worth ratio for four Asian economies. The findings of the study showed that reducing borrowing cost and increasing capital inflow resulted in financial liberalization, which encouraged excessive borrowing. The results confirmed Stein's theory that increasing excessive indebtedness indicates a financial crisis. Bekaert et al. (2005) confirmed that financial liberalization is one of the major constituents, contributing about 30\% to economic growth. Naveed and Mahmood (2019) investigated the important determinants of domestic financial policy variables to construct an index of financial sector liberalization for Pakistan. The index captured seven important financial dimensions by employing co-integration and VECM mechanisms. The results confirmed that the financial liberalization index has a positive impact on economic growth in the long term, while the short-term effect is found to be negative. The empirical finding of this study also concluded that financial intermediation and financial deepening are the most integral 
components for further reform implementation to encourage growth. Fry (1978) stated that financial sector liberalization encourages the supply as well as the allocation of resources for investment. Naghavi et al. (2018) examined the link between financial liberalization and stock market efficiency. The results indicated that financial sector liberalization has a positive and significant impact on stock market informational efficiency, though this liberalization is contingent on institutional development; according to econometric findings, neoliberalism is one of the major goals of the liberalization context. Ang and McKibbin (2007) reported that financial sector liberalization has a positive and significant effect on economic development in Malaysia. McKinnon (1973) and Shaw (1973) predicted that liberalized and positive interest rates would affect saving, capital accumulation channels and productive investment, which would lead to the economic growth of a country.

The previous literature constructed the financial sector liberalization index until 2010. This study was constructed to use the various fourteen financial policy indicators for the case of Pakistan for the first time-this was named a composite financial liberalization index. The important feature of this study is the use of updated data (until 2018) for 14 financial policy indicators using different sources such as the State Bank of Pakistan and Economic Survey of Pakistan. The main finding of this study was to develop a bidirectional index consisting of an average financial policy index, previously developed by Qureshi and Shah (2018), and a dummy-based financial policy index (based on magnitude and time with partial and gradual implementation) previously constructed by Shrestha and Chowdhury (2006).

The basis of a bi-directional and composite index essentially means that this study was limited to the McKinnon and Shaw framework, based on the construction of the financial liberalization index. However, there are some limitations to consider in the outcomes of the index. The limitations of the financial liberalization index are noteworthy. Firstly, the dummy variables are assigned the value of zero for regulation (control), and the value of one is given to the liberalized financial indicators. Secondly, a severe limitation in terms of post liberalization is that various studies used liberalization in a given time span: up until 2010. Aside from this, no proper composite index was constructed; therefore, this study encompasses the development of a financial liberalization index (FLI) for Pakistan. The study used secondary sources for data, which is already available in the public domain. Unlike primary sources, this is the firsthand information used to test precision in the context of financial and macroeconomic conditions in Pakistan.

Previous studies developed financial liberalization indexes to assess the degree of financial liberalization in a certain period of time in different parts of the world.

The process of financial liberalization involves the implementation of financial policies as directed above. The degree of financial sector liberalization over time can be obtained by means of constructing a financial liberalization index (FLI) for Pakistan by employing a principal component analysis (PCA).

Laeven (2000) and Bandiera et al. (2000) developed a financial liberalization index for eight of the least-developed countries, which included eight major financial indicators os the index: the ownership of banks, international financial liberalization, prudential regulation, financial stock market, interest rate, reserves requirement, measures competitiveness and credit control.

Previously, Demetriades and Luintel (1997) constructed a financial repression index for India using a principal component analysis. The index included nine political repression variables.

Referring to our work, Index A, Qureshi and Shah (2018) constructed a financial liberalization index (FLI) for Pakistan using nine financial policy indicators by employing a principal component analysis. A study by Lei and Tao (2017) measured China's financial liberalization index by employing a principal component analysis (PCA) and using seven financial policy indicators. The study categorized all of the financial indicators according to their respective outcomes. A comprehensive reflection of China's liberalization index can also expand the financial sector. 
With the same focus on our work, Index 2, Laurenceson and Chin (2003) constructed a financial repression index relating to China. Amaira and Amaira (2014) developed a financial liberalization index for Tunisia using a principal component analysis (PCA) to analyze 33 years. This study investigated the degree of financial liberalization in a single policy indicator. The study concluded with the measure of financial policy in terms of partial and fully liberalized context perspectives. Therefore, Tunisia's financial sector accelerated due to liberalization prospects:

- This study aim to measure the bi-directional financial liberalization index for Pakistan. On the surface, both indexes have a minor difference regarding their data, while the rest of the measurement process is likely similar. Index A is the average reform implication concept that summarizes the number of policies implemented in a whole period; for instance, privatization implemented a total number of eight policies from initiation. Index B is based on a dummy approach where a value of 0 indicates control/restriction and 1 indicates a regulated/liberalized stage regarding specific policy indicator, such as non-performing loans.

- The second and the most important stage in the methodology section is to create a composite model from fourteen financial policy indicators (financial reforms) with liberalizing variables known as a financial liberalization index. This index comprises various variables: Privatization, Non-performing loan, Institutional strengthening, Debt management, Monetary management, Exchange and payment reforms, Capital market, Banking reforms, Prudential regulation, Islamization, Interest rate deregulation, Credit control, Corporate risk and Removal of barrier to entry.

- The third stage is to study the data using a principle component analysis technique which gives us fourteen standard components, selected on the basis of variance in PCA1, PCA2, PCA3, ..... The reason for a higher acceptance rate of PCA is strongly correlated to the maximum variance of each PCA.

- A finalized PCA is selected due to maximum variance. The selected PCA then indicates the weightage of each financial policy indicator in the index model, such as Privatization, Non-performing loan, Removal of barrier to entry, etc.

- The fourth stage is to identify the best-fitted PCA for further analysis, which is finalized by the benchmarking of a scree plot. The PCA indication value (dots) lies above the benchmark and is considered to be a good fit for weightage.

\subsection{Index 1: Average Policy Implementing Year-Wise Base Index}

This study aimed to collect data from financial sector reforms, which were previously implemented by the Government of Pakistan from 1980 to 2018. A total number of 588 financial policies were implemented to construct the financial liberalization index for Pakistan. This study used two main sources for data collection. The first source is a financial sector assessment progress report published by the State Bank of Pakistan from 1990 to 2004. The second source of data is the Economic Survey of Pakistan, conducted from 2005 onward.

In present study, a principal component analysis (PCA) method was employed to construct a financial liberalization index $\left(\mathrm{FLI}_{\mathrm{t}}\right)$, incorporating 14 different variables that are categorized by the State Bank of Pakistan. The details of key theoretical factors influencing financial liberalization in Pakistan are as follows:

\section{Privatization}

Commercial bank privatization in Pakistan was one of the key outcomes in the context of financial liberalization in 1990s. Privatization is a process in which ownership is transferred from government-owned organizations and institutions to the private sector. However, in 1991, three foreign and ten private banks were allowed to operate in Pakistan. Similarly, 26 percent of shares were sold by the Muslim Commercial Bank (MCB) and Allied Bank Limited (ABL) to the private sector (State Bank of Pakistan 2003). 


\section{Non-Performing loan}

In 1992, the loans were classified on the basis of losses and doubtfulness loans. In 1996, one-fourth of loans in the financial sector, in the form of NPLs, collapsed. The problem of liquidity and disintermediation-caused losses increased. Due to an ineffective judicial system, the majority of loan defaults were unresolved. In 1997, SBP implemented a new scheme for loan defaulters to regularize and repay the payments (State Bank of Pakistan 2003).

\section{Institutional Strengthening}

The consolidation of the financial setup of the country's SBP introduced financial reforms to strengthen financial institutions. The key role of this reform was to refine the supremacy of the public, corporate and private sectors. Multi-dimensional and sensitive areas to these reforms were accountability, transparency, and rule of law. The introduction of a credit information bureau (CIB) was a major milestone in 1990s. CIB collected data from borrowers to form lending institutions. In 1991, the National Credit Commission (NCC) was founded for the evaluation of credit policy (State Bank of Pakistan 2003).

\section{Debt Management}

The main objective of this reform was to develop and implement schemes for debt management in order to encourage government funds. This attempt led to the achievement of effective markets for government securities (Kobayashi 2017). Likewise, efficient debt management minimized cost environment, and improved macroeconomic stability and the confidence of the investor to meet with low-cost conditions (Blommestein and Turner 2011). In 1991, SBP recognized the securities department in order to achieve public debt auction. Under financial liberalization, the Government of Pakistan introduced a secondary market for securities in 1998. (State Bank of Pakistan 2006). Debt management reforms helped to increase long-term debt and reduce the segmentation of the debt market. In December 2000, the Government issued three-, five- and ten-year investment bonds. Following the effective outcomes of these bonds, they were further extended to 20 years.

\section{Monetary Management}

The way of monetary stance has a direct impact on the financial sector of the country. The Government followed a monetarist approach in order to achieve fixed targets concerning foreign investment, growth rates and inflation. The term "monetary management" is trying to transform into "market structure" (Janjua 2005). In 1991, a minimum reserve 5 percent was kept constant in the State Bank of Pakistan by introducing Cash Reserve Requirement (CRR). The discount rate was kept at 14 percent in 2001; it was gradually decreased to 7.5 percent in 2002 (State Bank of Pakistan 2006). In 1992, a credit deposit was replaced with flexible deposit ratio in a quarter base.

\section{Exchange and payment reforms}

The foreign exchange is also called the international exchange, a market where currencies are bought and sold by one country to another country. In 1991, the government of Pakistan announced the exchange and payment reform, which could hold the foreign currency of Pakistani residents. The government also allowed foreign banks to take shares of up to $30 \%$ in publicly domestic companies. The State bank of Pakistan was liberalized to allow the foreign investor to transfer profit to their home country. Similarly, the technical fee payment ceiling was excluded for non-residents of the country. Multi-national companies (MNC) were allowed to generate funds and liberalized the remittances. The Government also liberalized and compensated borrowed funds from domestic companies (State Bank of Pakistan 2003).

\section{Capital Market}

Capital market plays a significant role in resources mobilization and channelizes them into a productive direction. It facilitates savers and investors by stimulating the economy in a positive direction. The capital market is a financial market where long-term debt and securities are sold and purchased. The capital market channelized the wealth into a long- 
term productive use for the saver to the companies and government in terms of investment. A long-term financial security can be traded by buyer and seller, bond and stock, etc. The development of the capital market program was initiated by the Asian Development Bank (ADB) and Government of Pakistan. Later on, commercial banks, International Finance Corporation (IFC) and Central Depository Companies (CDC) were introduce to transfer shares through the use of electronic technology (State Bank of Pakistan 2003).

\section{Banking Reforms}

A financial intermediary is one of the most important institutions in the financial sector; through intermediaries, a medium-large number of depositors and lenders can easily save and invest funds with interest rates. Some important initiatives were taken under the financial liberalization system such as insurance from banks for the depositor. In December 2000, efficient evening banking was started to facilitate clients and encourage economic health. State banks initiated a new banking reform to setup automatic teller machines (ATM) and restricted banks with higher returns on deposits for public agencies (Economic Survey of Pakistan 2014).

\section{Prudential Regulation}

In 1994, a prudential regulation was introduced by State Bank of Pakistan to strengthen the credit, banking, and governance systems of financial institutions. The objective was to sustain financial sector development, creating a healthy and prudential environment of banking. The aims of prudential regulations were to provide new financial procedures that compensated the society and economy of the country. Prudential regulation improves and measures regulatory frameworks and individual banking institutions. In the year 2003, different terminologies advocated for Non-Banking Financial Institution (NBFI), which covered capital companies, leasing, discount houses, housing finance companies and investment banks, in order to convert the insurance infrastructure to the Islamic mode and for the expansion of agriculture sector and takaful insurance (State Bank of Pakistan 2006).

\section{Islamization}

Pakistan started Islamization in the financial sector in 1980. Islamization in finance means the implementation of all financial concerns which are based on Islamic law and principles: small-business finance is based on interest-free, zakat, and modarabah companies, and the Investment Corporation of Pakistan (ICP) is based on the profits and losses of the investor. The commission of Islamization initiated a reduction in interest (riba) in 1991. The State Bank of Pakistan started Islamic banking parallel to conventional banking. Islamic banking started subsidiaries and Islamic financial products that were compliant with sharia law. SBP established a sharia board for the accounting of modarabah, ijara and musharikas (State Bank of Pakistan 2003).

\section{Interest Rate Deregulation}

In 1995, the interest rate was deregulated due to the elimination of the lending rate restrictions of banks and NBFIs. The restrictions to project financing and trade-related finance were also removed. Therefore, financial intermediaries determined lending rates through demand and supply in the market. The deregulation of interest rates created a competitive environment in the economy and benefited both the borrower and depositor (Khatiwada 1999).

\section{Removal of Entry Barrier}

The Government of Pakistan liberalized foreign and private banks with no restrictions and showed a competition efficiency toward the financial sector. In 1974, the private sector were allowed to introduce a banking system. All other non-financial institutions were encouraged to merge and operate in order to reduce inefficiencies. The private banks were liberalized, which also increased their market shares. 


\section{Credit Control}

Credit control is a system of credit through which customers are informed not to take a long time in the repaying of credit. The quantification of credit control includes banking rate policy, variable reserve ratios and open market operations, while the qualitative aspects of credit control are consumer regulation, direct control, and the regulation of margin requirement. Credit control is a major weapon in the financial sector used to direct monetary policy as well as to control the supply and demand of money.

\section{Stock Market Reforms}

The stock market plays a significant role in the financial sector, managing country domestic resources in the direction of productive investment. The stock market has a substantial association with the economy. The US news magazine, Business Weekly, declared that, in 2002, the Karachi Stock Exchange (KSE) was one of the best stock markets in the world. The stock market was improved by different policy makers in different directions. The concept of 100 indexes was introduced in 1991. The Security and Exchange Commission of Pakistan (SECP) came into existence with the implementation of corporate law authority in 1991. Similarly, KSE managed international investors through 'Reuters'. Likewise, KSE also appointed a large number of managers in the electronic transfer section to facilitate investors toward stocks. Pakistan Central Depository Company (CDC) maintained securities as electronic book entries, without any physical movement securities that could be transfer easily. Similarly, SECP also started a future trading program called a continuous funding system.

The description of the given financial variables for Pakistan are given below:

\subsection{Financial Liberalization Index $A$}

Table 1 shows the financial policies which are implemented each year. To construct the FLI for Pakistan, various reforms were recorded for each year. Therefore, there were eight (8) recorded reforms in the area of privatization, sixty-three (63) in institutional strengthening, twenty (20) in the area of non-performing loans, etc., which were implemented from 1980 to 2018. A total number of five hundred and eighty-eight (588) financial policies were implemented, and various dimensions of the financial sector were documented for developing the FLI for Pakistan.

The weight of a factor is calculated by employing a principal component analysis (PCA) method. The given model used to investigate financial liberalization index $\left(F L I_{t}\right)$ over time:

$$
\begin{gathered}
F L I_{t}=\Upsilon_{1}(P R I V)+\Upsilon_{2}(N P L)+\Upsilon_{3}(I N S T R)+\Upsilon_{4}(D M N G)+\Upsilon_{5}(M M N G)+\Upsilon_{6}(E X P A Y)+\Upsilon_{7}(C A P M)+\Upsilon_{8}(B N K) \\
+\Upsilon_{9}(P R U D)+\Upsilon_{10}(I S L M)+\Upsilon_{11}(I N T D R G)+\Upsilon_{12}(C C O N)+\Upsilon_{13}(C R I S K)+\Upsilon_{14}(R B A R)
\end{gathered}
$$

where, $t=1980,1981, \ldots \ldots, 2018$, and $\Upsilon_{t}$ is the weight of each component. When we measure the individual weight of each component, we followed the eigen vector or eigen value. The selection of the eigen value for each component was based on highest variance. The first principal component selected had 85 percent of variance, compared to the other components, and was placed into the following model:

$$
\begin{gathered}
\sum \lambda k=\lambda 1+\lambda 2+\lambda 3 \\
\sum \lambda k=2.894927+0.195689+0.29254 \\
\sum \lambda k=3.383156 \\
\lambda 1=\lambda 1 / \sum \lambda k \\
\lambda 1=2.894927 / 3.383156
\end{gathered}
$$


$F L I_{t}=0.079635(P R I V) t+0.14372($ INSTR $) t+0.079635(N P L) t+0.302181($ DMNG $) t+0.029744($ MMNG $) t$ $+0.447956($ EXPAY $) t+0.04941($ CAPM $) t+0.461934(B N K) t+0.390198(P R U D) t+0.435583($ ISLM $) t$ $+0.099243($ INTDRG $) t+0.113942($ CCON $) t+0.058387($ CRISK $) t+(-0.025902)(R B A R) t$

Table 1. Yearly implementation of financial liberalization reforms.

\begin{tabular}{|c|c|c|c|c|c|c|c|c|c|c|c|c|c|c|}
\hline YEAR & PRIV & INSTR & $N P L$ & $D M N G$ & $M M N G$ & EXPAY & $C A P M$ & $B N K$ & PRUD & ISLM & INTDRG & $\mathrm{CCON}$ & CRISK & $R B A R$ \\
\hline 1980 & 0 & 0 & 0 & 0 & 0 & 0 & 0 & 0 & 0 & 1 & 0 & 0 & 0 & 0 \\
\hline 1981 & 0 & 0 & 0 & 0 & 0 & 0 & 0 & 0 & 0 & 1 & 0 & 0 & 0 & 0 \\
\hline 1982 & 0 & 0 & 0 & 0 & 0 & 0 & 0 & 0 & 0 & 1 & 0 & 0 & 0 & 0 \\
\hline 1983 & 0 & 0 & 0 & 0 & 0 & 0 & 0 & 0 & 0 & 0 & 0 & 0 & 0 & 0 \\
\hline 1984 & 0 & 0 & 0 & 0 & 0 & 0 & 0 & 0 & 0 & 2 & 0 & 0 & 0 & 1 \\
\hline 1985 & 0 & 0 & 0 & 0 & 0 & 0 & 0 & 0 & 0 & 1 & 0 & 0 & 0 & 0 \\
\hline 1986 & 0 & 0 & 0 & 0 & 0 & 0 & 0 & 0 & 0 & 0 & 0 & 0 & 0 & 0 \\
\hline 1987 & 0 & 0 & 0 & 0 & 0 & 0 & 0 & 0 & 0 & 0 & 0 & 0 & 0 & 0 \\
\hline 1988 & 0 & 0 & 0 & 0 & 0 & 0 & 0 & 0 & 0 & 0 & 0 & 0 & 0 & 0 \\
\hline 1989 & 0 & 0 & 0 & 0 & 0 & 0 & 0 & 0 & 0 & 0 & 0 & 0 & 0 & 0 \\
\hline 1990 & 1 & 2 & 0 & 3 & 0 & 0 & 0 & 0 & 0 & 0 & 0 & 0 & 0 & 1 \\
\hline 1991 & 2 & 2 & 0 & 4 & 2 & 9 & 0 & 2 & 1 & 2 & 0 & 0 & 0 & 0 \\
\hline 1992 & 0 & 3 & 1 & 0 & 2 & 4 & 0 & 1 & 1 & 0 & 0 & 0 & 0 & 0 \\
\hline 1993 & 0 & 2 & 1 & 0 & 0 & 3 & 0 & 0 & 0 & 0 & 0 & 0 & 0 & 0 \\
\hline 1994 & 0 & 2 & 0 & 0 & 0 & 5 & 1 & 0 & 0 & 0 & 0 & 0 & 0 & 0 \\
\hline 1995 & 0 & 1 & 0 & 0 & 5 & 0 & 0 & 0 & 0 & 0 & 1 & 1 & 0 & 1 \\
\hline 1996 & 1 & 1 & 0 & 0 & 1 & 0 & 1 & 0 & 0 & 0 & 0 & 0 & 1 & 1 \\
\hline 1997 & 1 & 4 & 5 & 0 & 2 & 2 & 4 & 1 & 2 & 0 & 4 & 1 & 3 & 0 \\
\hline 1998 & 0 & 1 & 0 & 1 & 0 & 1 & 0 & 1 & 1 & 0 & 0 & 1 & 0 & 0 \\
\hline 1999 & 0 & 1 & 0 & 3 & 1 & 1 & 2 & 0 & 0 & 1 & 0 & 0 & 0 & 0 \\
\hline 2000 & 0 & 1 & 7 & 1 & 2 & 3 & 1 & 5 & 3 & 1 & 1 & 1 & 0 & 0 \\
\hline 2001 & 0 & 0 & 1 & 4 & 1 & 10 & 0 & 11 & 10 & 5 & 1 & 1 & 0 & 0 \\
\hline 2002 & 2 & 3 & 0 & 3 & 1 & 28 & 0 & 15 & 6 & 10 & 0 & 0 & 0 & 0 \\
\hline 2003 & 1 & 1 & 0 & 8 & 1 & 4 & 0 & 1 & 2 & 5 & 0 & 0 & 0 & 0 \\
\hline 2004 & 0 & 3 & 0 & 0 & 1 & 0 & 1 & 4 & 1 & 0 & 0 & 0 & 8 & 0 \\
\hline 2005 & 0 & 2 & 0 & 7 & 0 & 4 & 0 & 7 & 9 & 2 & 0 & 0 & 9 & 1 \\
\hline 2006 & 0 & 2 & 0 & 2 & 3 & 3 & 5 & 5 & 1 & 0 & 0 & 0 & 8 & 3 \\
\hline 2007 & 0 & 2 & 3 & 2 & 10 & 1 & 4 & 0 & 0 & 0 & 0 & 0 & 8 & 1 \\
\hline 2008 & 0 & 1 & 0 & 3 & 0 & 0 & 0 & 4 & 8 & 0 & 0 & 2 & 0 & 0 \\
\hline 2009 & 0 & 0 & 0 & 1 & 0 & 1 & 2 & 0 & 0 & 1 & 0 & 0 & 0 & 1 \\
\hline 2010 & 0 & 0 & 0 & 1 & 1 & 1 & 0 & 0 & 2 & 2 & 0 & 0 & 0 & 0 \\
\hline 2011 & 0 & 0 & 0 & 4 & 1 & 0 & 0 & 0 & 1 & 0 & 0 & 0 & 0 & 0 \\
\hline 2012 & 0 & 2 & 0 & 2 & 3 & 0 & 3 & 1 & 0 & 0 & 0 & 0 & 0 & 0 \\
\hline 2013 & 0 & 1 & 0 & 0 & 5 & 0 & 2 & 6 & 0 & 2 & 0 & 0 & 0 & 0 \\
\hline 2014 & 0 & 0 & 0 & 2 & 7 & 0 & 0 & 3 & 2 & 3 & 0 & 0 & 0 & 0 \\
\hline 2015 & 0 & 1 & 0 & 2 & 6 & 0 & 0 & 1 & 1 & 1 & 0 & 0 & 0 & 0 \\
\hline 2016 & 0 & 15 & 2 & 3 & 0 & 0 & 6 & 4 & 0 & 0 & 0 & 0 & 0 & 0 \\
\hline 2017 & 0 & 4 & 0 & 8 & 3 & 1 & 4 & 0 & 2 & 5 & 0 & 0 & 0 & 0 \\
\hline \multirow[t]{2}{*}{2018} & 0 & 6 & 0 & 1 & 2 & 0 & 4 & 8 & 10 & 1 & 0 & 0 & 0 & 0 \\
\hline & 8 & 63 & 20 & 65 & 60 & 81 & 40 & 80 & 63 & 47 & 7 & 7 & 37 & 10 \\
\hline
\end{tabular}


The scree plot indicated the best principal component, which has a high and desirable variance for obtaining the weightage of each financial variable. Therefore, the results of the scree plot show that the first six principal components have a maximum variance, which lies above or equal to 1 . The values of the principal component analysis above the horizontal straight line should be appropriate for determining the financial indicator weight.

It can be seen from Table 2 that the rate of the first principal component reaches $85.56 \%$ with the cumulative contribution; therefore, it should be reserved. The selection process of the principal component should be more clearly determined by the scree plot. In order to reduce the inaccuracy from the components, all of the outcomes of the selection to the principal component should be confirmed by the scree plot (see Figure 1).

Table 2. Eigen value and eigen vector of correlation matrix for policy variables.

\begin{tabular}{|c|c|c|c|}
\hline \multirow{2}{*}{ Variables } & \multicolumn{3}{|c|}{ Eigen Vector $(\lambda k)$} \\
\hline & $\lambda 1$ & $\lambda 2$ & $\lambda 3$ \\
\hline PRIV & 0.079635 & -0.359114 & -0.103161 \\
\hline INSTR & 0.14372 & 0.119263 & -0.547771 \\
\hline$N P L$ & 0.079635 & -0.359114 & -0.103161 \\
\hline$D M N G$ & 0.302181 & 0.238325 & -0.006544 \\
\hline$M M N G$ & 0.029744 & 0.17179 & 0.112813 \\
\hline EXPAY & 0.447956 & 0.009413 & -0.059264 \\
\hline$C A P M$ & 0.04941 & 0.222593 & -0.316596 \\
\hline$B N K$ & 0.461934 & 0.028378 & 0.121572 \\
\hline PRUD & 0.390198 & -0.092251 & 0.316465 \\
\hline ISLM & 0.435583 & 0.080888 & -0.060647 \\
\hline INTDRG & 0.099243 & -0.447401 & -0.00834 \\
\hline CCON & 0.113942 & -0.491814 & 0.335836 \\
\hline CRISK & 0.058387 & 0.335926 & 0.375471 \\
\hline$R B A R$ & -0.025902 & 0.387369 & 0.375823 \\
\hline en values $(\lambda k)$ & 2.894927 & 0.195689 & 0.29254 \\
\hline
\end{tabular}

Source: Own computation of SBP data through SPSS.

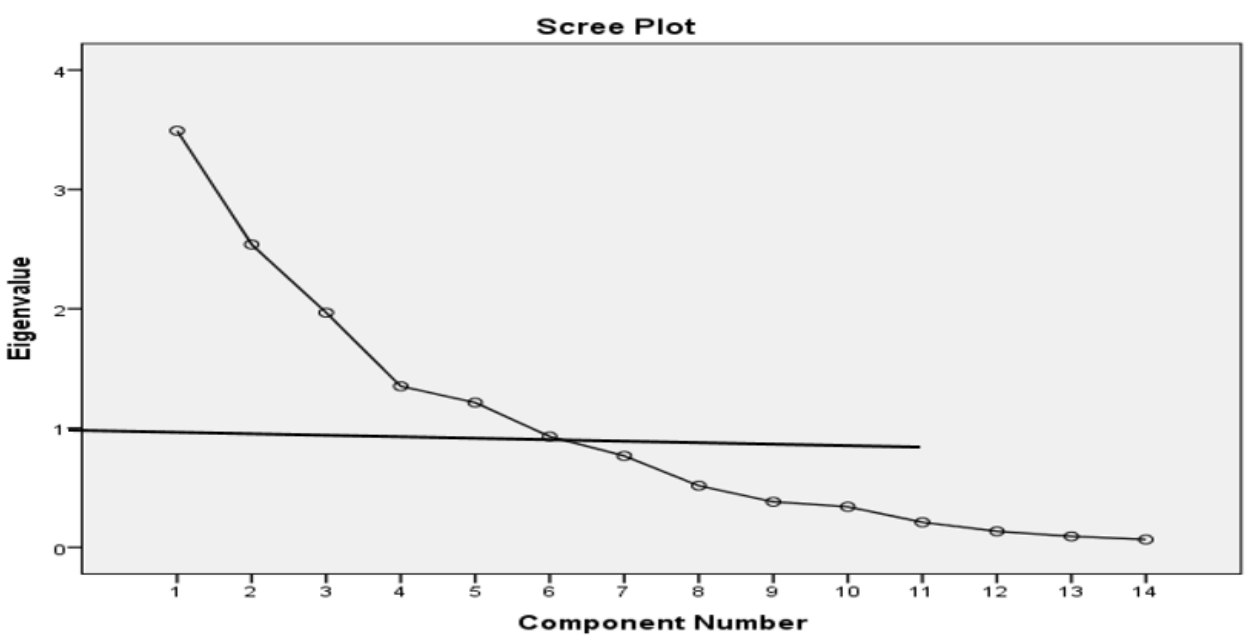

Figure 1. Scree plot of principal components. 
The method for measuring individual financial policy index is given below:

Year of implementation $=1991$

Name of variable $=$ Privatization $($ PRIV)

Total policy in 1991 to privatization $=2$

Sum of privatization policies from 1980-2018 = 8

Eigen value of privatization $=0.46193$ (weight of Privatization)

Privatization index value of $1991=$

Eigen value of privatization

Sum of all privatization policies from $1980-2018 \times$ Total policy in 1991 to privatization

Privatization index value of $1991=\frac{0.46193}{8 \times 2}$

Privatization index value of $1991=0.115483$

The above calculation indicates the measurement of individual financial policy for instance privatization for developing FLI for Pakistan. The year 1991 specifies the index value that only arises in the corresponding years. A total number of two policies were implemented in a given year, while eight was the overall total number of policies implanted from 1980-2018. The eigen value of 0.46193 specifies the weight of each policy indicator, such as privatization. The index value for the individual policy indicators are outlined through the abovementioned formula. The final index value of the specific year can be obtained by adding together all of the index values of the financial variables. The computation of the final index is shown in the given table (see Table A1 in Appendix A).

The above Figure 2 shows the year-wise index for financial liberalization, which includes the degree of financial liberalization with various dimensions. The study incorporated 14 elements with different aims, covering the stock markets, banks, capital markets and prudential regulation liberalization. The three stages of financial liberalization confirmed the boosting of outcomes prior to 1990, secondly in 1995, and finally from 2000 to 2003; however, from 2004 onward, liberalization remained in the equilibrium condition. The constant and smooth outcomes of the financial policy indicators of Pakistan, included in the existing study, was supported by one of the recent works conducted by Aslam and Akram (2018), which used the ordinary least square (OLS) technique to empirically investigate the effects of various financial reforms. The study concluded that, in the priority stage, the profitability of financial sector reforms was at a maximum, while the efficiency in the second period was recorded at its lowest level.

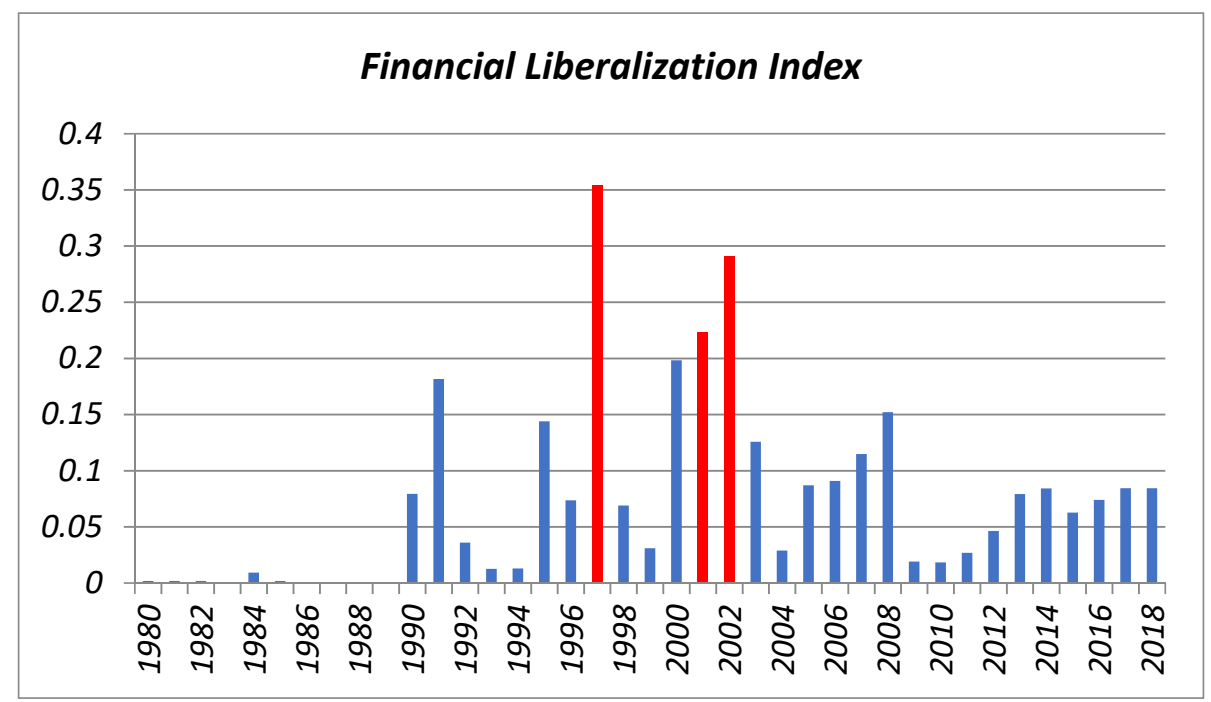

Figure 2. Number of financial liberalization policies implemented in relative years. 


\subsection{Financial Liberalization Index $B$}

Liberalized or Regulated (Dummy) Base Index

The following table shows the policies or financial reforms that were introduced for the first time. The cross sign in the box indicates a policy that was implemented to a respective financial indicator in a specified period of time.

Table 3 displays the financial liberalization system and sequence of initiation in the financial sector; the indication in the above sequence of financial efficiency regards each of the fourteen different measures. The crosses in the boxes indicate the year and the type of policy indicator processes that the phenomena effect. The number four indicates the implementation of liberalized institutional strengthening in 1990.

Table 3. The sequence of financial liberalization in Pakistan.

\begin{tabular}{|c|c|c|c|c|c|c|c|c|c|c|c|c|c|c|}
\hline Year of Policy Implementation & 1980 & 1984 & 1990 & 1990 & 1990 & 1991 & 1991 & 1991 & 1991 & 1992 & 1994 & 1995 & 1995 & 1996 \\
\hline PRIV & & & $X$ & & & & & & & & & & & \\
\hline INSTR & & & & $X$ & & & & & & & & & & \\
\hline$N P L$ & & & & & & & & & & $X$ & & & & \\
\hline$D M N G$ & & & & & $x$ & & & & & & & & & \\
\hline$M M N G$ & & & & & & $X$ & & & & & & & & \\
\hline EXPAY & & & & & & & $X$ & & & & & & & \\
\hline CAPM & & & & & & & & & & & $X$ & & & \\
\hline$B N K$ & & & & & & & & $X$ & & & & & & \\
\hline PRUD & & & & & & & & & $X$ & & & & & \\
\hline ISLM & $X$ & & & & & & & & & & & & & \\
\hline INTDRG & & & & & & & & & & & & $X$ & & \\
\hline CCON & & & & & & & & & & & & & $X$ & \\
\hline CRISK & & & & & & & & & & & & & & $X$ \\
\hline$R B A R$ & & $X$ & & & & & & & & & & & & \\
\hline Total & 1 & 2 & 3 & 4 & 5 & 6 & 7 & 8 & 9 & 10 & 11 & 12 & 13 & 14 \\
\hline
\end{tabular}

This study constructed a bi-directional financial liberalization index (FLI) for Pakistan. Therefore, some arbitrary values were given to each financial indicator on the basis of their productivity and its prior introduction. (See Table A1, Appendix A). Each financial indicator can have a value of 1 and 0 , respectively. Similarly, a value of 0 is assigned to those financial indicators that are regulated in a condition of governmental restriction or in the control of regulatory authorities, while a value of 1 was assigned to those financial policies which had an effective outcome and significant consequences on the growth rate of the economy.

Suggested financial policy indicators:

PRIV: Privatization

NPL: Non-performing loan

INSTR: Institutional strengthening

DMNG: Debt management

MMNG: Monetary management

EXPAY: Exchange and payment reforms

CAPM: Capital market

BNK: Banking reforms

PRUD: Prudential regulation

ISLM: Islamization

INTDRG: Interest rate deregulation

CCON: Credit control

CRISK: Corporate risk

RBAR: Removal of barrier to entry. 
Trend of the financial liberalization index is presented in Figure 3. However, there are some weaknesses to these financial policy indicators, including the zero digit in the above Table 4, which refers to the period before reforms implementation. It is necessary to expand the direction of these financial policy indicators to achieve the effective performance of the growth rate. Therefore, our work contributes to a composite index of fourteen variables that use the latest data.

Table 4. Financial liberalization on the basis of liberalized and regulated (dummy base).

\begin{tabular}{|c|c|c|c|c|c|c|c|c|c|c|c|c|c|c|}
\hline YEAR & PRIV & INSTR & $N P L$ & $D M N G$ & $M M N G$ & EXPAY & $C A P M$ & $B N K$ & PRUD & ISLM & INTDRG & $\mathrm{CCON}$ & CRISK & $R B A R$ \\
\hline 1980 & 0 & 0 & 0 & 0 & 0 & 0 & 0 & 0 & 0 & 1 & 0 & 0 & 0 & 0 \\
\hline 1981 & 0 & 0 & 0 & 0 & 0 & 0 & 0 & 0 & 0 & 1 & 0 & 0 & 0 & 0 \\
\hline 1982 & 0 & 0 & 0 & 0 & 0 & 0 & 0 & 0 & 0 & 1 & 0 & 0 & 0 & 0 \\
\hline 1983 & 0 & 0 & 0 & 0 & 0 & 0 & 0 & 0 & 0 & 1 & 0 & 0 & 0 & 0 \\
\hline 1984 & 0 & 0 & 0 & 0 & 0 & 0 & 0 & 0 & 0 & 1 & 0 & 0 & 0 & 1 \\
\hline 1985 & 0 & 0 & 0 & 0 & 0 & 0 & 0 & 0 & 0 & 1 & 0 & 0 & 0 & 1 \\
\hline 1986 & 0 & 0 & 0 & 0 & 0 & 0 & 0 & 0 & 0 & 1 & 0 & 0 & 0 & 1 \\
\hline 1987 & 0 & 0 & 0 & 0 & 0 & 0 & 0 & 0 & 0 & 1 & 0 & 0 & 0 & 1 \\
\hline 1988 & 0 & 0 & 0 & 0 & 0 & 0 & 0 & 0 & 0 & 1 & 0 & 0 & 0 & 1 \\
\hline 1989 & 0 & 0 & 0 & 0 & 0 & 0 & 0 & 0 & 0 & 1 & 0 & 0 & 0 & 1 \\
\hline 1990 & 1 & 1 & 0 & 1 & 0 & 0 & 0 & 0 & 0 & 1 & 0 & 0 & 0 & 1 \\
\hline 1991 & 1 & 1 & 0 & 1 & 1 & 1 & 0 & 1 & 1 & 1 & 0 & 0 & 0 & 1 \\
\hline 1992 & 1 & 1 & 1 & 1 & 1 & 1 & 0 & 1 & 1 & 1 & 0 & 0 & 0 & 1 \\
\hline 1993 & 1 & 1 & 1 & 1 & 1 & 1 & 0 & 1 & 1 & 1 & 0 & 0 & 0 & 1 \\
\hline 1994 & 1 & 1 & 1 & 1 & 1 & 1 & 1 & 1 & 1 & 1 & 0 & 0 & 0 & 1 \\
\hline 1995 & 1 & 1 & 1 & 1 & 1 & 1 & 1 & 1 & 1 & 1 & 1 & 1 & 0 & 1 \\
\hline 1996 & 1 & 1 & 1 & 1 & 1 & 1 & 1 & 1 & 1 & 1 & 1 & 1 & 1 & 1 \\
\hline 1997 & 1 & 1 & 1 & 1 & 1 & 1 & 1 & 1 & 1 & 1 & 1 & 1 & 1 & 1 \\
\hline 1998 & 1 & 1 & 1 & 1 & 1 & 1 & 1 & 1 & 1 & 1 & 1 & 1 & 1 & 1 \\
\hline 1999 & 1 & 1 & 1 & 1 & 1 & 1 & 1 & 1 & 1 & 1 & 1 & 1 & 1 & 1 \\
\hline 2000 & 1 & 1 & 1 & 1 & 1 & 1 & 1 & 1 & 1 & 1 & 1 & 1 & 1 & 1 \\
\hline 2001 & 1 & 1 & 1 & 1 & 1 & 1 & 1 & 1 & 1 & 1 & 1 & 1 & 1 & 1 \\
\hline 2002 & 1 & 1 & 1 & 1 & 1 & 1 & 1 & 1 & 1 & 1 & 1 & 1 & 1 & 1 \\
\hline 2003 & 1 & 1 & 1 & 1 & 1 & 1 & 1 & 1 & 1 & 1 & 1 & 1 & 1 & 1 \\
\hline 2004 & 1 & 1 & 1 & 1 & 1 & 1 & 1 & 1 & 1 & 1 & 1 & 1 & 1 & 1 \\
\hline 2005 & 1 & 1 & 1 & 1 & 1 & 1 & 1 & 1 & 1 & 1 & 1 & 1 & 1 & 1 \\
\hline 2006 & 1 & 1 & 1 & 1 & 1 & 1 & 1 & 1 & 1 & 1 & 1 & 1 & 1 & 1 \\
\hline 2007 & 1 & 1 & 1 & 1 & 1 & 1 & 1 & 1 & 1 & 1 & 1 & 1 & 1 & 1 \\
\hline 2008 & 1 & 1 & 1 & 1 & 1 & 1 & 1 & 1 & 1 & 1 & 1 & 1 & 1 & 1 \\
\hline 2009 & 1 & 1 & 1 & 1 & 1 & 1 & 1 & 1 & 1 & 1 & 1 & 1 & 1 & 1 \\
\hline 2010 & 1 & 1 & 1 & 1 & 1 & 1 & 1 & 1 & 1 & 1 & 1 & 1 & 1 & 1 \\
\hline 2011 & 1 & 1 & 1 & 1 & 1 & 1 & 1 & 1 & 1 & 1 & 1 & 1 & 1 & 1 \\
\hline 2012 & 1 & 1 & 1 & 1 & 1 & 1 & 1 & 1 & 1 & 1 & 1 & 1 & 1 & 1 \\
\hline 2013 & 1 & 1 & 1 & 1 & 1 & 1 & 1 & 1 & 1 & 1 & 1 & 1 & 1 & 1 \\
\hline 2014 & 1 & 1 & 1 & 1 & 1 & 1 & 1 & 1 & 1 & 1 & 1 & 1 & 1 & 1 \\
\hline 2015 & 1 & 1 & 1 & 1 & 1 & 1 & 1 & 1 & 1 & 1 & 1 & 1 & 1 & 1 \\
\hline 2016 & 1 & 1 & 1 & 1 & 1 & 1 & 1 & 1 & 1 & 1 & 1 & 1 & 1 & 1 \\
\hline 2017 & 1 & 1 & 1 & 1 & 1 & 1 & 1 & 1 & 1 & 1 & 1 & 1 & 1 & 1 \\
\hline 2018 & 1 & 1 & 1 & 1 & 1 & 1 & 1 & 1 & 1 & 1 & 1 & 1 & 1 & 1 \\
\hline
\end{tabular}




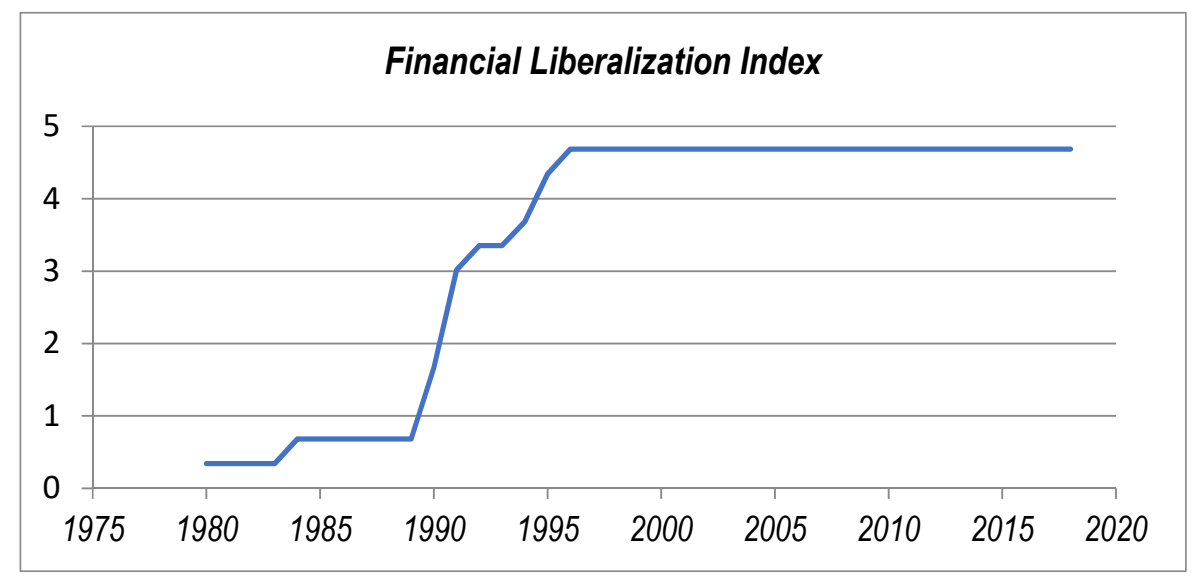

Figure 3. Financial liberalization index (FLI).

The cross signs in Table 3 indicate the initial implementation period when financial liberalization in Pakistan was achieved. However, the weight of each financial indicator is achieved by employing a principal component analysis (PCA). The composition of the financial liberalization index (FLI) for Pakistan can be expressed as follows:

$$
\begin{gathered}
F L I_{t}=\Upsilon_{1}(\mathrm{PRIV})+\Upsilon_{2}(\mathrm{NPL})+\Upsilon_{3}(\mathrm{INSTR})+\Upsilon_{4}(\mathrm{DMNG})+\Upsilon_{5}(\mathrm{MMNG})+\Upsilon_{6}(\mathrm{EXPAY})+\Upsilon_{7}(\mathrm{CAPM})+\Upsilon_{8} \\
\left.(\mathrm{BNK})+\Upsilon_{9}(\mathrm{PRUD})+\Upsilon_{10}(\mathrm{ISLM})\right)+\Upsilon_{11}(\mathrm{INTDRG})+\Upsilon_{12}(\mathrm{CCON})+\Upsilon_{13}(\mathrm{CRISK})+\Upsilon_{14}(\mathrm{RBAR}) \\
\sum \lambda k=\lambda 1+\lambda 2 \\
\sum \lambda k=12.126+0.635 \\
\sum \lambda k=12.7613 \\
\lambda 1=\lambda 1 / \sum \lambda k \\
\lambda 1=12.126 / 12.7613 \\
\lambda 1=0.95020(95 \% \text { Variance of } \mathrm{PC} 1 \text { or } \lambda 1)
\end{gathered}
$$

The above Figure 4 illustrates the level of variance in term of various weightage of financial policy indicators. The given plot directed the best principal component, which has a high and desirable variance for obtaining the weightage of each financial variable. Therefore, the results of the above scree plot express that the first three principal components have a maximum variance, which lies above or equal to 1 respectively. The values of the principal component analysis above the horizontal straight line should be appropriate for determining the financial indicator weight especially for developing index 2 . However, the benchmarking value of Scree Plot for determining the best principle component is 1 . In case of the above Scree Plot the first eigenvalue is recorded a high variance $85.56 \%$ which has been used for the measurement of second index construction.

$$
\begin{gathered}
F L I_{t}=0.947(P R I V)+0.956(N P L)+0.947(I N S T R)+0.947(D M N G)+0.972(M M N G)+0.972(E X P A Y)+ \\
0.915(C A P M)+0.972(B N K)+0.972(\text { PRUD })+0.305(I S L M)+0.890(I N T D R G)+0.890(C C O N)+0.852 \\
\text { (CRISK) + 0.590 (RBAR) }
\end{gathered}
$$

The index to a single component for the financial liberalization policy indicator is calculated by substituting the values of (PRIV, NPL, INSTR, DMNG, MMNG, EXPAY, CAPM, BNK, PRUD, ISLM, INTDRG, CCON, CRISK and RBAR) in Table 5, multiplied by the respective values of $Y 1$. The index of financial liberalization for a specified year would be computed by adding the calculated value of all of the financial policy indicators for the year concerned. The individual year or the overall time period of the financial liberalization index (FLI) is calculated (see Table A2 in Appendix A). 


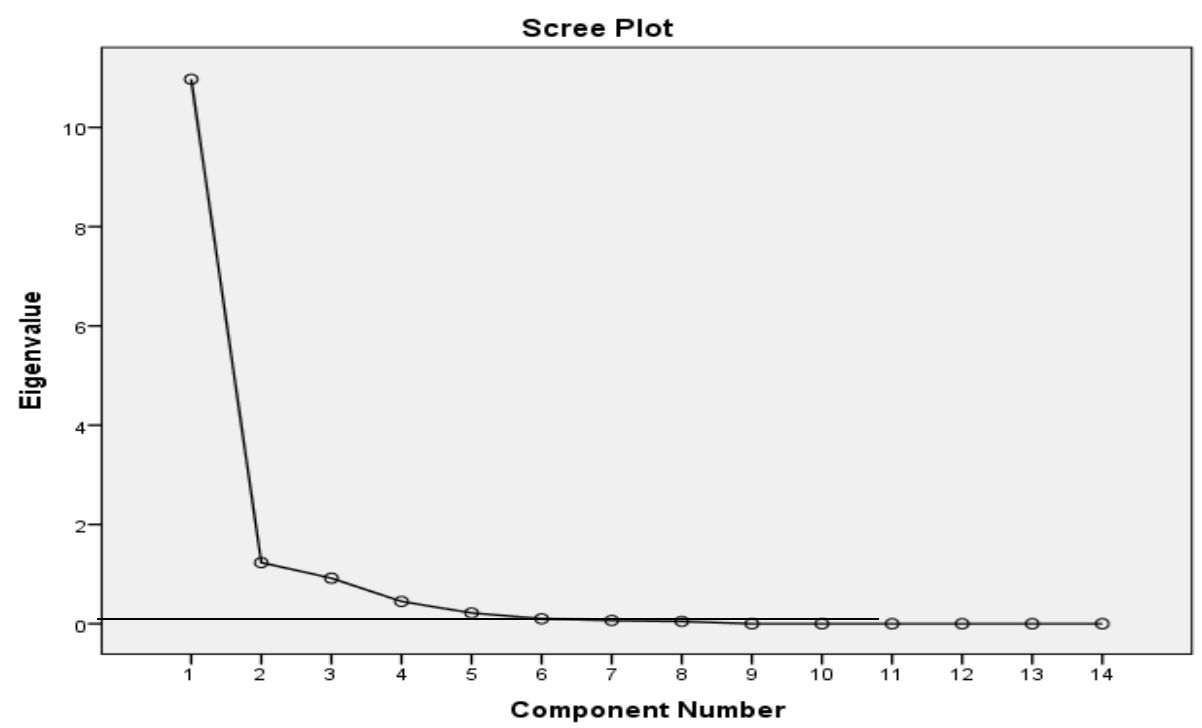

Figure 4. Scree plot of principle components.

Table 5. Principle component analysis results.

\begin{tabular}{|c|c|c|c|}
\hline \multicolumn{4}{|c|}{ Principle Matrix Components } \\
\hline \multirow{2}{*}{ S/No } & \multirow{2}{*}{ Variables Descriptions } & \multicolumn{2}{|c|}{ Components } \\
\hline & & PC1 & $P C 2$ \\
\hline 1 & PRIV & 0.947 & 0.123 \\
\hline 2 & INSTR & 0.947 & 0.123 \\
\hline 3 & $N P L$ & 0.956 & -0.061 \\
\hline 4 & DMNG & 0.947 & 0.123 \\
\hline 5 & $M M N G$ & 0.972 & 0.036 \\
\hline 6 & EXPAY & 0.972 & 0.036 \\
\hline 7 & $C A P M$ & 0.915 & -0.231 \\
\hline 8 & $B N K$ & 0.972 & 0.036 \\
\hline 9 & PRUD & 0.972 & 0.036 \\
\hline 10 & ISLM & 0.305 & 0.732 \\
\hline 11 & INTDRG & 0.890 & -0.292 \\
\hline 12 & CCON & 0.890 & -0.292 \\
\hline 13 & CRISK & 0.852 & -0.302 \\
\hline \multirow[t]{2}{*}{14} & $R B A R$ & 0.590 & 0.572 \\
\hline & & $\Lambda 1=12.126$ & $\Lambda 2=0.635$ \\
\hline
\end{tabular}

Total variance explained (95\%) in case of first principal component (PC1).

\section{Policy Implication}

This paper proposes an exclusive approach to creating a financial liberalization index for a developing economy such as Pakistan's. Therefore, very few studies of financial liberalization that have a theoretical character are available. We formulated a financial liberalization index to gauge the financial liberalization index of Pakistan. This paper provides both methodological and theoretical perspectives for relevant insights.

On the basis of the empirical results of the outcomes of financial liberalization index form Pakistan, the following policies should be targeted to help the policy maker. The analytical outcomes of financial sector efficiency through reforms are consistent in their nature of liberalized setup. Therefore, it is an immense challenge for policy makers to 
measure the factual policy of the financial sector in terms of reforms with different policy indicators. Griffith-Jones et al. (2003) and Singh (2003) state that financial sector liberalization adversely affects the growth rate of the country and can make it more vulnerable to financial crashes. The present research work, which uses various financial liberalization policy indicators as a major concert of the IMF, SBP and GOP, is inconsistent according to the given results. The existing financial policies should track financial liberalization, which is consistent with a limited stability. It is not a desirable status of liberalization, but promotes the development process and welfare of the economy without making it vulnerable.

Financial crisis is brought to the forefront by means of various important regulations for financial companies and banks. One of the most prominent research works on this topic, by Joseph Stiglitz, warns us that market volatility is expected to become more intense in the near future. The capability of risk monitoring needs to strengthen financial companies and commercial banks toward prosperous strategies. These strategies are needed for the financial liberalization of a damaged economy.

- In the light of the abovementioned results, this study directed some policy recommendations in a broad sense. Financial liberalization is carried out on the basis of financial reforms to help the financial sector of a country. In contrast, financial liberalization also discourages inefficient activities such as increasing interest rates and non-performing loans toward the financial sector.

- The efficient trending of policies in the above results justifies the introduction of more reforms in the financial sector of Pakistan. The reforms succeeded in moving the financial sector from a repressed environment to a market-based indirect system of monetary, exchange, and credit management. The reforms also removed distortions and segmentation in the financial markets and intensified the competition among financial institutions in the country. Therefore, the trends in the highlighted results and graphical representation of the financial liberalization index provide a valuable insight into appropriate directions for policy makers.

- There is no denying that financial liberalization carried out under broad-based financial restructuring/financial reform helped to make the financial sector more flexible, resilient, and deep, as well as helping the financial institutions of the country.

- Pakistan's financial sector policies require some reforms to adjust to the changing economic environment. The policies should be geared toward more incentives and the elimination of financial sector barriers. This will help the country to attract more foreign banks, foreign investors, as well as multinational companies, and thus investments that promote growth. More incentives should be provided to the qualified investors who are interested in investing in Pakistan.

\section{Conclusions}

This paper presents a theoretical model for constructing a financial liberalization index in a developing country such as Pakistan. In this paper, the financial liberalization index (FLI) for Pakistan was developed, which comprised fourteen different financial liberalization policy indicators that were implemented during the last two decades of the liberalization period. The index is based on a factorial approach by employing principal component analysis (PCA) to a large number of liberalization data. A bi-directional index was constructed according to the features of the data: firstly, the average year-wise financial liberalization index, and secondly, a dummy-based financial liberalization index. The study further explained that the index outcomes highlighted three major pros and cons on the basis of liberalized policy implementation; very few reforms were initiated between 1990 and 1996. The study further suggested that the liberalization reforms to each financial policy indicator accelerated from 1997 to 2003, correspondingly, whereas, from 2003 onwards, the liberalization process was sluggish, with a constant and smooth direction up to the present day. The findings of this study are surprising and unique to the financial sector of Pakistan because an index of fourteen composite financial indicators recorded consistent 
reforms from their initiation up to 2018. This study corroborates various studies conducted in various parts of the world for measuring the degree of financial liberalization, such as Amaira and Amaira (2014), Demetriades and Luintel (1997) and Bandiera et al. (2000). This study found that corporate risk, in terms of better access to finance, was also raised as a consequence of financial liberalization. Financial liberalization also resulted in a decrease in the cost of capital and improved corporate governance in Pakistan.

\section{Limitation and Future Study}

This study is based on data of the developing economy of Pakistan; therefore, it may not be applicable to another economy without taking its socio-economic and financial indicators into account. For future studies, researchers in financial and economic sectors may work to find comparisons between lagging and leading economies to obtain more insights into financial liberalization in a global context.

Author Contributions: Conceptualization, M.I. and U.H.; methodology, M.S.A.; software, A.R.; validation, A.R., M.I. and M.S.A.; formal analysis, U.H.; investigation, M.R.; resources, A.R.; data curation, A.R.; writing—original draft preparation, M.P.; writing—review and editing, M.R.; visualization, M.P.; supervision, M.I.; project administration, U.H.; funding acquisition, M.R. and M.P. All authors have read and agreed to the published version of the manuscript.

Funding: No funding was received for this research.

Institutional Review Board Statement: Not applicable.

Informed Consent Statement: Not applicable.

Data Availability Statement: Data are publicly available as stated into the article.

Conflicts of Interest: The authors declare no conflict of interest. 


\section{Appendix A}

Table A1. Average year-wise financial liberalization index.

\begin{tabular}{|c|c|c|c|c|c|c|c|c|c|c|c|c|c|c|c|}
\hline$Y E A R$ & PRIV & INSTR & $N P L$ & $D M N G$ & $M M N G$ & EXPAY & $C A P M$ & $B N K$ & PRUD & ISLM & INTDRG & CCON & CRISK & $R B A R$ & $F L I$ \\
\hline 1980 & 0 & 0 & 0 & 0 & 0 & 0 & 0 & 0 & 0 & 0.001694 & 0 & 0 & 0 & 0 & 0.001694 \\
\hline 1981 & 0 & 0 & 0 & 0 & 0 & 0 & 0 & 0 & 0 & 0.001694 & 0 & 0 & 0 & 0 & 0.001694 \\
\hline 1982 & 0 & 0 & 0 & 0 & 0 & 0 & 0 & 0 & 0 & 0.001694 & 0 & 0 & 0 & 0 & 0.001694 \\
\hline 1983 & 0 & 0 & 0 & 0 & 0 & 0 & 0 & 0 & 0 & 0 & 0 & 0 & 0 & 0 & 0 \\
\hline 1984 & 0 & 0 & 0 & 0 & 0 & 0 & 0 & 0 & 0 & 0.003389 & 0 & 0 & 0 & 0.005839 & 0.009228 \\
\hline 1985 & 0 & 0 & 0 & 0 & 0 & 0 & 0 & 0 & 0 & 0.001694 & 0 & 0 & 0 & 0 & 0.001694 \\
\hline 1986 & 0 & 0 & 0 & 0 & 0 & 0 & 0 & 0 & 0 & 0 & 0 & 0 & 0 & 0 & 0 \\
\hline 1987 & 0 & 0 & 0 & 0 & 0 & 0 & 0 & 0 & 0 & 0 & 0 & 0 & 0 & 0 & 0 \\
\hline 1988 & 0 & 0 & 0 & 0 & 0 & 0 & 0 & 0 & 0 & 0 & 0 & 0 & 0 & 0 & 0 \\
\hline 1989 & 0 & 0 & 0 & 0 & 0 & 0 & 0 & 0 & 0 & 0 & 0 & 0 & 0 & 0 & 0 \\
\hline 1990 & 0.057741 & 0.001569 & 0 & 0.014165 & 0 & 0 & 0 & 0 & 0 & 0 & 0 & 0 & 0 & 0.005839 & 0.079314 \\
\hline 1991 & 0.115483 & 0.001569 & 0 & 0.018886 & 0.014932 & 0.015969 & 0 & 0.01089 & 0.000472 & 0.003389 & 0 & 0 & 0 & 0 & 0.181588 \\
\hline 1992 & 0 & 0.002353 & 0.005697 & 0 & 0.014932 & 0.007097 & 0 & 0.005445 & 0.000472 & 0 & 0 & 0 & 0 & 0 & 0.035996 \\
\hline 1994 & 0 & 0.001569 & 0 & 0 & 0 & 0.008872 & 0.002481 & 0 & 0 & 0 & 0 & 0 & 0 & 0 & 0.012921 \\
\hline 1995 & 0 & 0.000784 & 0 & 0 & 0.03733 & 0 & 0 & 0 & 0 & 0 & 0.044129 & 0.055743 & 0 & 0.005839 & 0.143825 \\
\hline 1996 & 0.057741 & 0.000784 & 0 & 0 & 0.007466 & 0 & 0.002481 & 0 & 0 & 0 & 0 & 0 & -0.0007 & 0.005839 & 0.073612 \\
\hline 1997 & 0.057741 & 0.003137 & 0.028485 & 0 & 0.014932 & 0.003549 & 0.009924 & 0.005445 & 0.000943 & 0 & 0.176514 & 0.055743 & -0.0021 & 0 & 0.354313 \\
\hline 1998 & 0 & 0.000784 & 0 & 0.004722 & 0 & 0.001774 & 0 & 0.005445 & 0.000472 & 0 & 0 & 0.055743 & 0 & 0 & 0.06894 \\
\hline 1999 & 0 & 0.000784 & 0 & 0.014165 & 0.007466 & 0.001774 & 0.004962 & 0 & 0 & 0.001694 & 0 & 0 & 0 & 0 & 0.030846 \\
\hline 2000 & 0 & 0.000784 & 0.039879 & 0.004722 & 0.014932 & 0.005323 & 0.002481 & 0.027224 & 0.001415 & 0.001694 & 0.044129 & 0.055743 & 0 & 0 & 0.198326 \\
\hline 2001 & 0 & 0 & 0.005697 & 0.018886 & 0.007466 & 0.017743 & 0 & 0.059892 & 0.004717 & 0.008472 & 0.044129 & 0.055743 & 0 & 0 & 0.222746 \\
\hline 2002 & 0.115483 & 0.002353 & 0 & 0.014165 & 0.007466 & 0.049681 & 0 & 0.081671 & 0.00283 & 0.016945 & 0 & 0 & 0 & 0 & 0.290593 \\
\hline
\end{tabular}


Table A1. Cont.

\begin{tabular}{|c|c|c|c|c|c|c|c|c|c|c|c|c|c|c|c|}
\hline YEAR & PRIV & INSTR & NPL & $D M N G$ & $M M N G$ & EXPAY & CAPM & $B N K$ & PRUD & ISLM & INTDRG & CCON & CRISK & $R B A R$ & $F L I$ \\
\hline 1980 & 0 & 0 & 0 & 0 & 0 & 0 & 0 & 0 & 0 & 0.001694 & 0 & 0 & 0 & 0 & 0.001694 \\
\hline 1981 & 0 & 0 & 0 & 0 & 0 & 0 & 0 & 0 & 0 & 0.001694 & 0 & 0 & 0 & 0 & 0.001694 \\
\hline 1982 & 0 & 0 & 0 & 0 & 0 & 0 & 0 & 0 & 0 & 0.001694 & 0 & 0 & 0 & 0 & 0.001694 \\
\hline 1983 & 0 & 0 & 0 & 0 & 0 & 0 & 0 & 0 & 0 & 0 & 0 & 0 & 0 & 0 & 0 \\
\hline 1984 & 0 & 0 & 0 & 0 & 0 & 0 & 0 & 0 & 0 & 0.003389 & 0 & 0 & 0 & 0.005839 & 0.009228 \\
\hline 1985 & 0 & 0 & 0 & 0 & 0 & 0 & 0 & 0 & 0 & 0.001694 & 0 & 0 & 0 & 0 & 0.001694 \\
\hline 1987 & 0 & 0 & 0 & 0 & 0 & 0 & 0 & 0 & 0 & 0 & 0 & 0 & 0 & 0 & 0 \\
\hline 1988 & 0 & 0 & 0 & 0 & 0 & 0 & 0 & 0 & 0 & 0 & 0 & 0 & 0 & 0 & 0 \\
\hline 1989 & 0 & 0 & 0 & 0 & 0 & 0 & 0 & 0 & 0 & 0 & 0 & 0 & 0 & 0 & 0 \\
\hline 1990 & 0.057741 & 0.001569 & 0 & 0.014165 & 0 & 0 & 0 & 0 & 0 & 0 & 0 & 0 & 0 & 0.005839 & 0.079314 \\
\hline 1991 & 0.115483 & 0.001569 & 0 & 0.018886 & 0.014932 & 0.015969 & 0 & 0.01089 & 0.000472 & 0.003389 & 0 & 0 & 0 & 0 & 0.181588 \\
\hline 1992 & 0 & 0.002353 & 0.005697 & 0 & 0.014932 & 0.007097 & 0 & 0.005445 & 0.000472 & 0 & 0 & 0 & 0 & 0 & 0.035996 \\
\hline 1994 & 0 & 0.001569 & 0 & 0 & 0 & 0.008872 & 0.002481 & 0 & 0 & 0 & 0 & 0 & 0 & 0 & 0.012921 \\
\hline 1995 & 0 & 0.000784 & 0 & 0 & 0.03733 & 0 & 0 & 0 & 0 & 0 & 0.044129 & 0.055743 & 0 & 0.005839 & 0.143825 \\
\hline 1996 & 0.057741 & 0.000784 & 0 & 0 & 0.007466 & 0 & 0.002481 & 0 & 0 & 0 & 0 & 0 & -0.0007 & 0.005839 & 0.073612 \\
\hline 1997 & 0.057741 & 0.003137 & 0.028485 & 0 & 0.014932 & 0.003549 & 0.009924 & 0.005445 & 0.000943 & 0 & 0.176514 & 0.055743 & -0.0021 & 0 & 0.354313 \\
\hline 1998 & 0 & 0.000784 & 0 & 0.004722 & 0 & 0.001774 & 0 & 0.005445 & 0.000472 & 0 & 0 & 0.055743 & 0 & 0 & 0.06894 \\
\hline 1999 & 0 & 0.000784 & 0 & 0.014165 & 0.007466 & 0.001774 & 0.004962 & 0 & 0 & 0.001694 & 0 & 0 & 0 & 0 & 0.030846 \\
\hline 2000 & 0 & 0.000784 & 0.039879 & 0.004722 & 0.014932 & 0.005323 & 0.002481 & 0.027224 & 0.001415 & 0.001694 & 0.044129 & 0.055743 & 0 & 0 & 0.198326 \\
\hline 2001 & 0 & 0 & 0.005697 & 0.018886 & 0.007466 & 0.017743 & 0 & 0.059892 & 0.004717 & 0.008472 & 0.044129 & 0.055743 & 0 & 0 & 0.222746 \\
\hline 2002 & 0.115483 & 0.002353 & 0 & 0.014165 & 0.007466 & 0.049681 & 0 & 0.081671 & 0.00283 & 0.016945 & 0 & 0 & 0 & 0 & 0.290593 \\
\hline
\end{tabular}


Table A2. Dummy-based financial liberalization index.

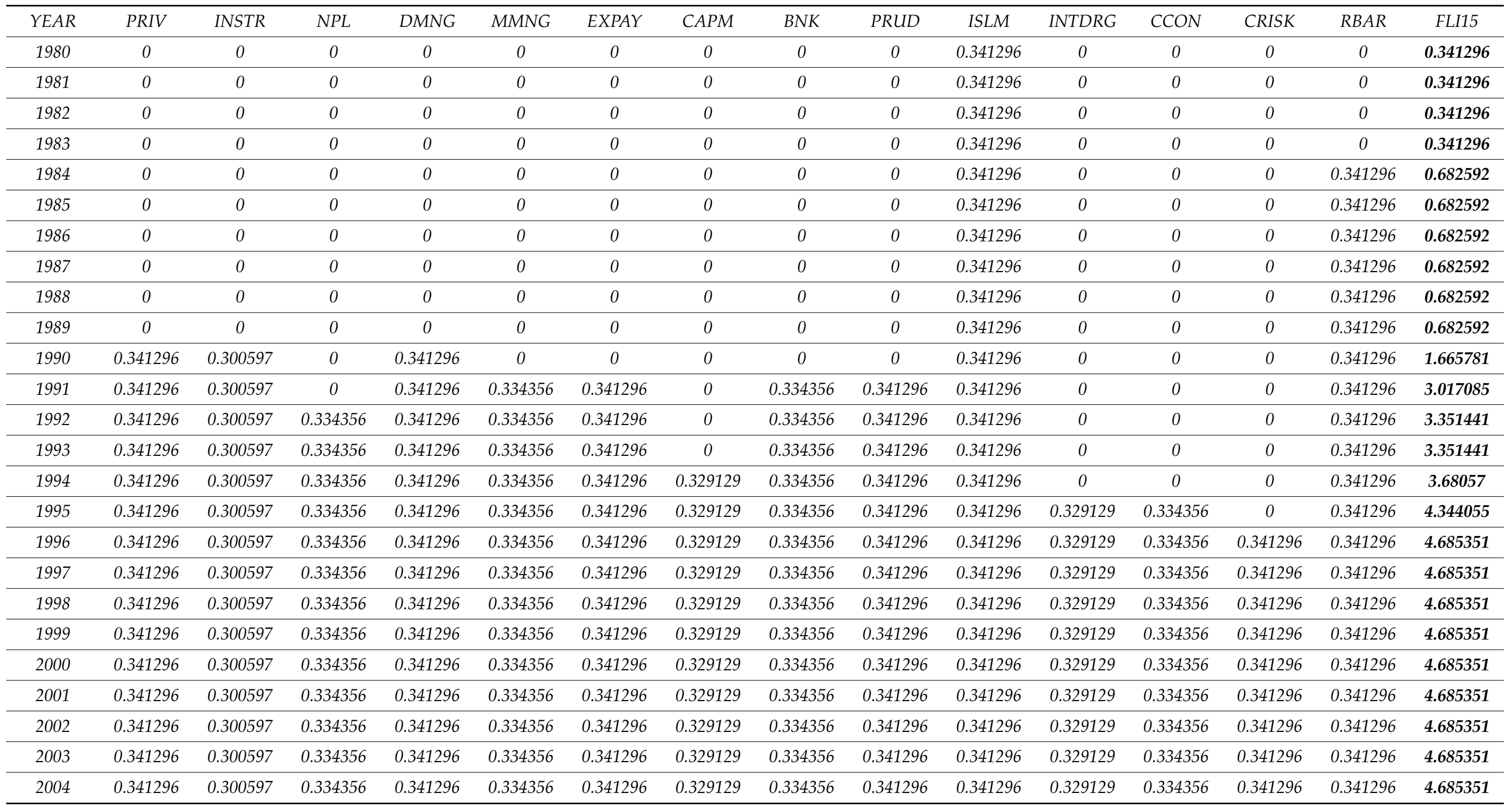


Table A2. Cont.

\begin{tabular}{|c|c|c|c|c|c|c|c|c|c|c|c|c|c|c|c|}
\hline$Y E A R$ & PRIV & INSTR & $N P L$ & $D M N G$ & $M M N G$ & EXPAY & $C A P M$ & $B N K$ & PRUD & ISLM & INTDRG & CCON & CRISK & $R B A R$ & FLI15 \\
\hline 2005 & 0.341296 & 0.300597 & 0.334356 & 0.341296 & 0.334356 & 0.341296 & 0.329129 & 0.334356 & 0.341296 & 0.341296 & 0.329129 & 0.334356 & 0.341296 & 0.341296 & 4.685351 \\
\hline 2006 & 0.341296 & 0.300597 & 0.334356 & 0.341296 & 0.334356 & 0.341296 & 0.329129 & 0.334356 & 0.341296 & 0.341296 & 0.329129 & 0.334356 & 0.341296 & 0.341296 & 4.685351 \\
\hline 2007 & 0.341296 & 0.300597 & 0.334356 & 0.341296 & 0.334356 & 0.341296 & 0.329129 & 0.334356 & 0.341296 & 0.341296 & 0.329129 & 0.334356 & 0.341296 & 0.341296 & 4.685351 \\
\hline 2008 & 0.341296 & 0.300597 & 0.334356 & 0.341296 & 0.334356 & 0.341296 & 0.329129 & 0.334356 & 0.341296 & 0.341296 & 0.329129 & 0.334356 & 0.341296 & 0.341296 & 4.685351 \\
\hline 2009 & 0.341296 & 0.300597 & 0.334356 & 0.341296 & 0.334356 & 0.341296 & 0.329129 & 0.334356 & 0.341296 & 0.341296 & 0.329129 & 0.334356 & 0.341296 & 0.341296 & 4.685351 \\
\hline 2010 & 0.341296 & 0.300597 & 0.334356 & 0.341296 & 0.334356 & 0.341296 & 0.329129 & 0.334356 & 0.341296 & 0.341296 & 0.329129 & 0.334356 & 0.341296 & 0.341296 & 4.685351 \\
\hline 2011 & 0.341296 & 0.300597 & 0.334356 & 0.341296 & 0.334356 & 0.341296 & 0.329129 & 0.334356 & 0.341296 & 0.341296 & 0.329129 & 0.334356 & 0.341296 & 0.341296 & 4.685351 \\
\hline 2012 & 0.341296 & 0.300597 & 0.334356 & 0.341296 & 0.334356 & 0.341296 & 0.329129 & 0.334356 & 0.341296 & 0.341296 & 0.329129 & 0.334356 & 0.341296 & 0.341296 & 4.685351 \\
\hline 2013 & 0.341296 & 0.300597 & 0.334356 & 0.341296 & 0.334356 & 0.341296 & 0.329129 & 0.334356 & 0.341296 & 0.341296 & 0.329129 & 0.334356 & 0.341296 & 0.341296 & 4.685351 \\
\hline 2014 & 0.341296 & 0.300597 & 0.334356 & 0.341296 & 0.334356 & 0.341296 & 0.329129 & 0.334356 & 0.341296 & 0.341296 & 0.329129 & 0.334356 & 0.341296 & 0.341296 & 4.685351 \\
\hline 2015 & 0.341296 & 0.300597 & 0.334356 & 0.341296 & 0.334356 & 0.341296 & 0.329129 & 0.334356 & 0.341296 & 0.341296 & 0.329129 & 0.334356 & 0.341296 & 0.341296 & 4.685351 \\
\hline 2016 & 0.341296 & 0.300597 & 0.334356 & 0.341296 & 0.334356 & 0.341296 & 0.329129 & 0.334356 & 0.341296 & 0.341296 & 0.329129 & 0.334356 & 0.341296 & 0.341296 & 4.685351 \\
\hline 2017 & 0.341296 & 0.300597 & 0.334356 & 0.341296 & 0.334356 & 0.341296 & 0.329129 & 0.334356 & 0.341296 & 0.341296 & 0.329129 & 0.334356 & 0.341296 & 0.341296 & 4.685351 \\
\hline
\end{tabular}




\section{References}

Adeel-Farooq, Rana Muhammad, Nor Aznin Abu Bakar, and Jimoh Olajide Raji. 2017. Trade openness, financial liberalization, and economic growth: The case of Pakistan and India. South Asian Journal of Business Studies 6: 229-46. [CrossRef]

Akhtar, Syed Mohammed Jawed, and Md Shabbir Alam. 2011. Banking System in India: Reforms and Performance Evaluation. Delhi: New Century Publications.

Alam, Md Shabbir, Mustafa Raza Rabbani, Rumzi Mohammad Tausif, and Joji Abey. 2021. Banks' Performance and Economic Growth in India: A Panel Cointegration Analysis. Economies 9: 38. [CrossRef]

Amaira, Bouzid, and Radhia Amaira. 2014. Financial Liberalization Index of Tunisia: Factorial Method Approach. International Journal of Economics, Finance and Management Sciences 2: 206-11. [CrossRef]

Ang, James B., and Warwick J. McKibbin. 2007. Financial liberalization, financial sector development and growth: Evidence from Malaysia. Journal of Development Economics 84: 215-33. [CrossRef]

Arphasil, Prakarn. 2001. Financial Liberalization and Financial Crisis: The Case of Thailand. Aldershot: Ashgate Publishing Limited.

Aslam, Muhammad, and Zeeshan Akram. 2018. Financial Sector Liberalization and Efficiency: Evidence from Pakistan. Minhaj Journal of Economics and Organization Science 1: 35-50.

Azmeh, Chadi, Hazem Al Samman, and Sulaiman Mouselli. 2017. The Impact of Financial Liberalization on Economic growth: The Indirect Link. International Business Management 11: 1289-97.

Bagehot, Walter. 1873. Lombard Street, 1962th ed. Homewood: Richard D. Irwin.

Bandiera, Oriana, Gerard Caprio, Patrick Honohan, and Fabio Schiantarelli. 2000. Does Financial Reform Raise or Reduce Saving? Review of Economics and Statistics 1: 239-63. [CrossRef]

Beim, David O., and Charles W. Calomiris. 2001. Emerging Financial Markets. New York: McGraw Hill Higher Education.

Bekaert, Geert, Campbell R. Harvey, and Christian Lundblad. 2005. Does financial liberalization spur growth? Journal of Financial Economics 77: 3-55. [CrossRef]

Blommestein, Hans J., and Philip Turner. 2011. Interactions between Soverign Debt Management and Monetary Policy Under Fiscal Dominance and Financial Instability. Available online: https:/ / papers.ssrn.com/sol3/papers.cfm?abstract_id=1964627 (accessed on 2 October 2021).

Bui, Tat Dat, Mohd Helmi Ali, Feng Ming Tsai, Mohammad Iranmanesh, Ming-Lang Tseng, and Ming K. Lim. 2020. Challenges and Trends in Sustainable Corporate Finance: A Bibliometric Systematic Review. Journal of Risk and Financial Management 13: 264. [CrossRef]

Celik, Tuncay, and Levent Citak. 2016. Banking Competition, Financial Liberalization and Economic Growth: Evidence from Turkish Economy during the 1990-2014 Period. International Journal of Economics and Financial Issues 6: 1750-55.

Demetriades, Panicos, and Svetlana Andrianova. 2004. Finance and growth: What we know and what we need to know. In Financial Development and Economic Growth. London: Palgrave Macmillan UK, pp. 38-65.

Demetriades, Panicos O., and Kul B. Luintel. 1997. The direct costs of financial repression: Evidence from India. Review of Economics and Statistics 79: 311-20. [CrossRef]

Economic Survey of Pakistan. 2014. Available online: http:/ /www.finance.gov.pk/survey_0708.html (accessed on 2 October 2021).

Fry, Maxwell. 1978. Money and capital or financial deepening in economic development? Journal of Money, Credit and Banking 10: 464-75. [CrossRef]

Goldsmith, Raymond W. 1969. Financial Structure and Development. New Haven: Yale University Press.

Griffith-Jones, Stephany, Ricardo Gottschalk, and Xavier Cirera. 2003. The OECD experience with Capital Account Liberalization. In Management of Capital Flows: Comparative Experiences and Implications for Africa. New York and Geneva: United Nations.

Hye, Qazi Muhammad Adnan, and Shahida Wizarat. 2013. Impact of financial liberalization on economic growth: A case study of Pakistan. Asian Economic and Financial Review 3: 270.

Janjua, M. Ashraf. 2005. Money supply, inflation and economic growth: Issues in monetary management in Pakistan. The Lahore Journal of Economics, 73-105. [CrossRef]

Johnston, Barry, and V. Sundararajan. 1999. Sequencing Financial Sector Reforms: Country Issues and Experiences. Washington, DC: International Monetary Fund.

Khan, Muhammad Arshad, and Abdul Qayyum. 2007. Trade, Financial and Growth Nexus in Pakistan, Economic Analysis. Working Paper 6: 1-24.

Khatiwada, Yuba Raj. 1999. An Overview of Financial Liberalization and Agenda for Further Reforms. In Do We Need Economic Reforms Phase II. Kathmandu: Institute for Integrated Development Studies.

Kiyota, Kozo, Barbara Pietsch, and Robert Stern. 2007. The case for Financial Sector Liberalization in Ethiopia. Available online: https:/ / deepblue.lib.umich.edu/handle/2027.42/55484 (accessed on 2 October 2021).

Kobayashi, Shinya. 2017. Insurance and financial stability: Implications of the Tsunami view for regulation and supervision of insurers. Journal of Financial Regulation and Compliance 25: 105-12. [CrossRef]

Laeven, Luc. 2000. Financial Liberalization and Financing Constraints: Evidence from Panel Data on Emerging Economies. Washington, DC: World Bank, Financial Sector Strategy and Policy Department.

Laurenceson, James, and Joseph C. H. Chin. 2003. Financial Reform and Economic Development in China. Cheltenham: Edward Elgar Publishing. 
Lei, Nie, and Shigui Tao. 2017. The Construction and Analysis of Financial Liberalization Index of China. International Journal of Business and Economics Research 6: 48. [CrossRef]

Mattoo, Aaditya, Randeep Rathindran, and Arvind Subramanian. 2006. Measuring services trade liberalization and its impact on growth: An illustration. Journal of Economic Integration 21: 64-98. [CrossRef]

McKinnon, R. 1973. Money and Capital in Economic Development. Washington, DC: The Brookings Institution.

Morris, Felipe, Mark Dorfman, Jose Pedro Ortiz, and Maria Claudia Franco. 1990. Latin America's Banking Systems in the 1980s-A Cross-Country Comparison. Washington, DC: World Bank, Discussion Paper No. 81.

Munir, Salma, Imran Sharif Chaudhry, and Mohammad Hanif Akhtar. 2013. Financial Liberalization and Economic Growth in Pakistan: Empirical Evidence from Co-integration Analysis. Pakistan Journal of Social Sciences (PJSS) 33: 227-41.

Naghavi, Navaz, Muhammad Shujaat Mubarik, and Devinder Kaur. 2018. Financial Liberalization and Stock Market Efficiency: Measuring the Threshold effects of Governance. Annals of Financial Economics 13: 1-24. [CrossRef]

Naveed, Samina, and Zafar Mahmood. 2019. Impact of domestic financial liberalization on economic growth in Pakistan. Journal of Economic Policy Reform 22: 16-34. [CrossRef]

Okoye, Lawrence U., Clement I. N. Nwakoby, Nwanneka J. Modebe, and Uchechukwu Emenas Okorie. 2016. Impact of economic liberalization on the growth of the Nigerian economy (1986-2015). African Banking and Finance Review 2: 87-100.

Pineda, Percival. 2017. Financial liberalization and private sector borrowing in ASEAN 4 economies 1990-2012. Eurasian Economic Review 7: 277-95. [CrossRef]

Qureshi, Salman Ali, and Syed Muhammad Amir Shah. 2018. Financial Liberalization Index of Pakistan: Factorial Approach. Abasyn Journal of Social Sciences 2: 49-61.

Rojas-Suárez, Ms Liliana, and Mr Steven Riess Weisbrod. 1995. Financial fragilities in Latin America: The 1980s and 1990s. Washington, DC: International Monetary Fund.

Shaw, Edward Stone. 1973. Financial Deepening in Economic Development. New York: Oxford University Press.

Shrestha, Min B., and Khorshed Chowdhury. 2006. Financial liberalization index for Nepal. International Journal of Applied Econometrics and Quantitative Studies 3: 41-54.

Singh, A. 2003. Capital Account Liberalization, Free Long-Term Capital Flows, Financial Crisis and Economic Development. Eastern Economic Journal 29: 191-216.

State Bank of Pakistan. 2003. Financial Sector Assessment Progress Report 2002-2003. Available online: www.sbp.org.pk (accessed on 2 October 2021)

State Bank of Pakistan. 2006. Financial Sector Assessment Progress Report 2005-2006. Available online: www.sbp.org.pk (accessed on 2 October 2021).

Tang, Liujie, and Chang Liu. 2018. Analysis of the Financial Liberalization Degree in Vietnam Based on Mattoo Index. Advances in Economics, Business and Management Research 58: 233-37.

Williamson, John, and Molly Mahar. 1998. A Survey of Financial Liberalization. Princeton: Princeton University, Department of Economics Essays in International Finance No. 211. 